\title{
The Influence of Community Empowerment, Organizational Commitment, and Organization Learning on Performance of MSMEs South Minahasa Regency-Indonesia
}

\author{
Johny Taroreh, Allen A. Ch. Manongko \\ Faculty of Economics, Manado State University-Indonesia
}

\begin{abstract}
The aims of this research are to analyze the influence of (1) Community Empowerment on the performance of MSMEs (2) Learning organization on the performance of MSMEs (3) Community Empowerment on Organizational Commitment (4) Learning Organization on Commitment. This research used Quantitative method by involving 354 samples comprising the owners (for variable of the performance of MSMEs) and employees (for variable of learning organization, community empowerment and organizational commitment). This research was conducted at MSMEs in 17 districts of South Minahasa Regency. Data analysis technique used is SEM (structural equation modeling) and the CFA test (Confirmatory Analysis factor). Models were tested by comparing the model alignment criteria.The results of the research show that four variables are directly significant or proven to be influential. Those variables are: (1) Community Empowerment to the performance of MSMEs (2) Learning Organization directly influences the performance of MSMEs (3) Community Empowerment directly influences Organizational Commitment (4) Learning Organization to Organizational Commitment. Exogenous variables (learning organization, community empowerment) are proved to have an impact on the performance of MSMEs. The findings in this study lead to the need for the development of economic education curriculum such as training, as well as mentoring process, as an effort to improve human resources.
\end{abstract}

Keywords: Community Empowerment, Organizational Commitment, Learning Organization, Performance of MSMEs

DOI: $10.7176 / \mathrm{EJBM} / 11-18-05$

Publication date:June $30^{\text {th }} 2019$

\section{Introduction}

Micro, Small and Medium Enterprises (MSMEs) undeniably play an important role as the backbone of the national economy. There are some evident indicators which show how important this sector is in order to support the Indonesian economy such as the number of MSMEs in 2013 reaching 56, 5 million business units or $99.9 \%$ of total business in Indonesia (source: Kompas, 25 October 2013). Its contribution to the national economy is $57,95 \%$ of 4,303.57 trillion, with total investment value of Rp 830.9 trillion of gross domestic product (GDP), and Micro, Small and Medium Enterprises (MSMEs) absorb labor at 110.80 million people. Data from the Ministry of Cooperatives and Micro, Small and Medium Enterprises (MSMEs) in 2013 show that the total number of Micro, Small and Medium Enterprises (MSMEs) in Indonesia reached 56.5 million units, or equivalent to 99.9 percent of the total business units in Indonesia (source: Kompas, 25 February 2014).

Since Micro, Small and Medium Enterprises undergo many obstacles in realizing their role, the government as an institution must pay more attention in order to guarantee the role of SMEs (Bank Indonesia, 2013). The potential of MSMEs contributes to Gross Domestic Product (GDP) much higher than 58\%. The contribution of MSME has a bigger proportion than big business groups, but it does not result from their high productivity. According to Tambunan (2009: 60), this bigger proportion is the result of their number of units instead of its productivity (total or partial). Furthermore, Tambunan (2008: 1-2) reported the empirical studies which explain that " MSMEs have low contribution to the economic condition in developing countries, and it results from low education level or skills of workers and employers, lack of capital, impartial government policies which lead to MSMEs distortion. Budiretnowati (2008: 14) added "the knowledge of MSME owners about the economic value of goods to be produced is low, so and MSMEs do not get the benefits from the added value they have produced.

In 2014, the Regional Government of South Minahasa District undertook a strategy of increasing the promotion and marketing of small industries / crafts which linked to the development of tourism. Therefore, the government had efforts to determine that the location of industrial activities or any company is accesible for the tourists. The UMKM sector had contributed 20\% to the PDRB of South Minahasa Regency in 2013.Problems found in the development of science and technology in MSMEs can be grouped into two categories, those are internal problems and external problems.

Internal problems include: (1) Low awareness and willingness of employers to apply science and technology in the company. (2) Limited capital to make improvements / improvements in technology. (3) Lack of entrepreneur ability to seize business opportunity. (4) low access and limited information on certain sources of technology and knowledge. While external problems are as follows. (1) The process of technology transfer to MSMEs is not 
optimal, due to limited personnel. (2) Scheme of financing for the development of science and technology including the purchase of new machines for MSME is still limited. For example, leasing systems to buy machinery / equipment are still limited. MSME less use this system because it is not competitive.

\section{Literature Review}

\subsection{Community Empowerment}

Empowerment terminology continues to evolve along with changes in society, Oxaa and Baden (1997) in Utami 2007, defining empowerment originating from the origin of the word "power" which can be understood as: (1) power over, power to avoid domination and subordination, threats of crime and intimidation; (2) power to, the strength associated with the ability to make decisions, authority, problem solving and creativity; (3) power with, the power to cooperate in order to achieve a common goal; and (4) power within, strengths in the form of selfconfidence, awareness, and firmness.

More specifically, empowerment can be interpreted as a planned and systematic process, which is carried out on an ongoing basis, both for individuals or collectives, in order to develop the power (potential) and abilities that are within themselves so as to be able to carry out social transformation. Community empowerment can also be interpreted as an effort to develop, empower, empower, and strengthen the bargaining position of the grassroots community to pressure forces in all sectors and sectors of life through the transfer of decision making to the community so that they are accustomed and able to be responsible for everything they choose ( Suharto. 2005; Dubois \& Milley, 2005).

The concept of empowerment is basically an effort to make the atmosphere of a just and civilized humanity become more structurally effective, both in family life, society, state, regional, international, as well as economic, political and others (Pranata et al. 1996). Empowerment can also be interpreted as an effort to increase the capacity of the community to deal with their future needs by providing resources, opportunities, knowledge and skills. (Ife 1995).

Another concept of empowerment is pointing to the ability of people, especially vulnerable and weak groups so that they have the strength or ability of people, especially vulnerable and weak groups so that they have the strength and ability to (a) fulfill their basic needs so that they have (fredoom) not only free to express opinions, but free from ignorance, free from pain; (b) reaching productive resources that enable them to increase their income and obtain the goods and services they need; and (c) participate in the development process and decisions that affect them (Suharto, 2005)

\subsection{Organizational Commitment}

Organizational Commitment According to Meyer \& Allen in Guylane and Vandenberghe (2009: 7) suggest that "Commitment is a global psychological state that characterizes the relationship between employees and organizations." From the statement above, commitment is a psychological condition as a whole that is characterized by the relationship between employees and organizations . Furthermore, Meyer and Allen in Luthan (2008: 147) stated that commitment is an attitude that describes employee loyalty to the company. Employees who have organizational commitment are employees who have a strong desire to become the main members of their organization, have a strong willingness to work and strive for the benefit of the organization, have trust and acceptance of the values and goals of the organization. Porter et al. in Kedsuda and Ogunlana (2007: 167) define the word "commitment" as the strength of an individual identified by involvement in a particular organization. Furthermore, Porter et al. suggests that commitment has three main components: strong belief (presumption) and acceptance of organizational goals and values; a willingness to use a large enough business in the name of the organization; and one limited desire to maintain organizational membership.

According to Mathis and Jackson (2006: 122) provide a definition of "Organizational Commitment is the degree to which employees believe in and accept organizational goals and desires to remain with the organization." From the definition above, organizational commitment is the level to where employees are sure and accept goals organization and desires to live with the organization. Furthermore, Mathis and Jackson (2006: 122) suggest that people who are relatively satisfied with their work will be more committed to the organization and people who are committed to the organization are more likely to get greater satisfaction.

Robbin (2009: 113) states that organizational commitment "A state in which an employee identifies with a particular organization and goals and wishes to maintain membership in the organization." From the statement above, organizational commitment is a condition in which an employee takes sides certain organizations and their objectives and are interested in maintaining membership in the organization. Furthermore, he emphasized the alignments of employees with respect to the organization and the sincerity of employees towards achieving organizational goals and the efforts of employees to survive.

\subsection{Learning Organization}

The term learning organization was originally popularized by Peter Senge, a director of MIT's Organizational 
Learning Center (Massachusetts Institute of Technology) in his book Fifth Discipline. Peter Senge (1999) says that learning organizations are where people continually expand their results truly truly, where they are, where people are continually learning, and where people are continually learning to see the whole together. Curtis and Philip (2001: 551) also said that: Members of the organization to develop models, tools and techniques for their change and grow faster than competitors.

From the two notions of organizational experts above, it can be concluded that the learning organization is an organization that people in it together continually strive to develop themselves and continue to learn in order to face business competition and changes in the environment around the organization. According to Lipshitz's learning organization and colleague (2002) "it is painstakingly dependent on the willingness of people to care and share knowledge with others". The application of the principle of learning at work offers an opportunity to develop trust and communication among different individuals, who have jointly identified learning as their primary goal.

\section{Theoritical Framework}

3.1. Correlation between learning organization and organizational commitment.

Xianting, Fungfai (2010) conducted a study to determine the impact of organizational learning culture on the results of the mentoring practices in the AEC industry (the Architucture, Engineering, and Contruction Industry) which led to an increase in organizational commitment. The research samples were 269 young industry professionals of AEC in Hongkong. The results showed that organizational learning culture has a positive relationship with guidance practices. It also showed that guidance practices have a positive impact on organizational commitment, and finally organizational learning culture has a positive relationship with organizational commitment through counseling practice.

\subsection{The correlation of learning organization and the performance of MSME}

Hurly and Hult's (1998) research entitled Innovation, Market Orientation and Organizational: An Intregration and Empirical Examination. In this research, the researchers established a conceptual framework that explained that the characteristics of organizational structures and processes as well as the cultural characteristics drive the innovation of an organization. It will ultimately affect the competitive advantage and company performance. The variables studied were the size and the resources, and the cultural variables leading to the innovations examined were learning and development, status differences, support and collaboration, power sharing and resistance to conflict. The study was conducted on 56 groups of companies and the results of analysis were: a) the size of groups and cultures that encourage innovation affect the capacity of innovation in employees. b) The higher the dimensions of innovation culture such as participation, support and collaboration, power sharing, organizational development and learning, the higher the organizational innovation.

The similarity between Hurley and Hult's (1998) and this research is that both research focus on organizational learning variables. However, Hurley and Hult's (1998) research revealed that organizational learning is believed to have an effect on the capacity of innovation which will affect the employee's performance. That research has not been empirically tested but the influence of organizational learning on employee performance will be tested empirically.

\subsection{The correlation of Community Empowerment and MSMEs Performance.}

M.J. Xavier, J. Raja and S. Usha Nanhini (2006) conducted a study entitled Entrepreunership Development through Corporate Intervention between Self Help Group in India, The Case of HLLs Project Shakti. This study aims to determine the impact of Hindustan Lever Limited company intervention through empowerment project named Shakti to women - women self-help group. The variables observed were the criteria of entrepreneurship development, economic empowerment, social empowerment, the interrelationship between the three and the formulation of an integrated model illustrating the relationship of the three. The analytical technique used is Narrative Analysis which aims to evoke the entrepreneurs' response to family background, work character and lifestyle. The results of this study indicates that the intervention through Shakti Project to micro entrepreneurs triggered the existence of business continuity. Economic empowerment resulted in business independence, and social empowerment resulted in leadership.

Guy Vincent's research (2005) entitled The Roles of Microfinance, Entrepreneurship and Sustainability in Reducing Poverty in LDCs aimed to study 1) the relationship between microfinance, entrepreneurship and sustainability in poverty reduction in developing countries, 2) the influence of micro entrepreneurship in reducing poverty and empowering the community. The study used microfinance theory and the role of entrepreneurship in reducing poverty and focused on sustainability in reducing poverty. The results of the study showed that (1) economic benefits - entrepreneurship leads to a promising process of development (2) social development and impact, microfinance allows improvements in the quality of life of micro-entrepreneurs (3) microfinance presence stabilizes cash flow of MSMEs and secures the business. 


\subsection{The correlation of Empowerment and Organizational Commitment}

In addition to a vital organizational asset, Human Resources (employees) are internal customers who determine the final quality of a product or service and organization. However, in the reality, many organizations exploit their employees and do not provide opportunities for them to grow and perform optimally. The worst situation happens when the owners and employees do not trust each other. This condition is possible due to low working spirit and work morale, productivity, apathy and work dissatisfaction and the decrease of organizational commitment (Corsun and Enz (1999). Koberg et al. (1999) stated that empowerment will affect organizational commitment

Furthermore, the conceptual model that will be studied in this research is presented in the following figure:

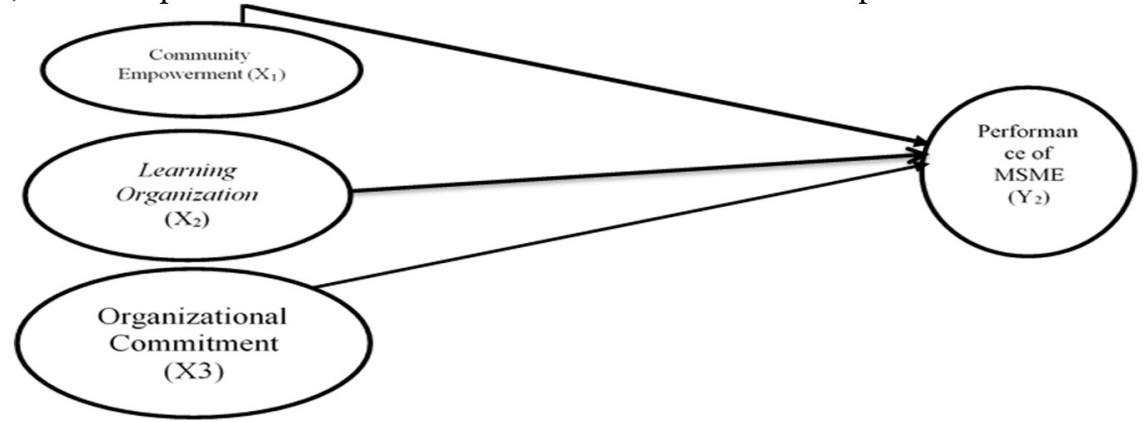

Figure 1. Research Conceptual Model

This conceptual model is so simple and presents the status of each research variables, those are antecedent variables and consequences. Antecedent variables consist of learning organization, community empowerment and organizational commitment. These variables affect each other. The result variable is the performance of MSMEs.

\section{Hypothesis}

H1: Variable of community empwerment influences directly to the MSMEs performance

$\mathrm{H} 2$ : Variable of Learning Organization influences directly to MSMEs performance

$\mathrm{H} 3$ : Variable of community empowerment influences directly to organizational commitment

$\mathrm{H} 4$ : Variable of learning organization influences directly to the organizational commitment

\section{Method Research}

In this research, the respondents of the research are the owners of MSMEs. The research was conducted in MSMEs in 17 districts of South Minahasa Regency. The magnitude of $\mathrm{N}$ is determined by the research population. The size of the population can be seen from the number of units of MSMEs in 17 districts of South Minahasa Regency. The size is presented in the following table.

Table 1. Research Population

\begin{tabular}{|l|l|c|c|c|}
\hline No & \multicolumn{1}{|c|}{ Districts } & $\begin{array}{c}\text { Micro Business } \\
\text { (unit) }\end{array}$ & $\begin{array}{c}\text { Small Business } \\
\text { (unit) }\end{array}$ & $\begin{array}{c}\text { Medium-scale Business } \\
\text { (unit) }\end{array}$ \\
\hline 1 & Modoinding & 351 & 97 & 213 \\
\hline 2 & Tompaso Baru & 235 & 86 & 195 \\
\hline 3 & Maesaan & 124 & 39 & 113 \\
\hline 4 & Ranoyapo & 227 & 146 & 33 \\
\hline 5 & Motoling & 364 & 81 & 203 \\
\hline 6 & Kumelembuai & 82 & 11 & 128 \\
\hline 7 & Motoling Barat & 34 & 0 & 202 \\
\hline 8 & Motoling Timur & 89 & 45 & 315 \\
\hline 9 & Sinonsayang & 135 & 109 & 413 \\
\hline 10 & Tenga & 424 & 200 & 315 \\
\hline 11 & Amurang & 520 & 252 & 257 \\
\hline 12 & Amurang Barat & 178 & 146 & 180 \\
\hline 13 & Amurang Timur & 156 & 106 & 64 \\
\hline 14 & Tareran & 257 & 71 & 218 \\
\hline 15 & Suluun Tareran & 38 & 28 & 154 \\
\hline 16 & Tumpaan & 447 & 165 & 3230 \\
\hline 17 & Tatapaan & 241 & 50 & 1632 \\
\hline & Amount & 3899 & & \\
\hline & & & Total N 8761 & \\
\hline
\end{tabular}

Source : Industry and Coorperation Department, South Minahasa Regency

The size of samples is determined by using sampling without replacement with $5 \%$ error rate. This proportion 
equation was developed by Daniel and Terrel (1989). The total samples are 54 respondents. The population is stratified, so to accurately describe about the properties of a heterogeneous population, the researcher uses Proposional random sampling.

Community Empowerment refers to Tri Widodo Utomo (2004). Its dimensions include Business Counseling, Service Business Facility, Market Development, Assistance. Organizational Commitment refers to Meyer and Allen in Luthan (2008: 147). Its dimensions include Affective, Sustainability and Normative. The performance of MSME refers to Maynard in Riyanti 2003; Robbins 2001; Terziouski and Samson 2000, Brealey and Gitmen in Sangen M.2005. Its Dimensions include Level of income for the last 3 years, gain set aside, Growth volume for the last 3 years, Market coverage, self-satisfaction as an entrepreneur, working conditions, the growth of labor, the frequency of community conflicts around due to the use of tools / machinery, environment.

In this research, the data analyzed serve as primary data. They refer to data directly obtained from the respondents through questionnaires. Instruments built from research variables in accordance with the references are used to provide an overview of the empirical conditions. Through the instrument, respondents give response by providing self-rating on statements or question based on their experiences. Laggomarsino and Cardona (2003) suggest that self-rating is adequate for studies involving self-conceptualization. The research instrument uses measurement with likert scale or commonly referred to as summated ratings (Coolican, 1994). It consists of the values of the responses on the scale contained in the instrument which can be summed up.

\section{Result and Discussion}

\subsection{Result}

In testing stage, early-simulation process in this conceptual research aims to find out the fulfillment of alignment requirements for a model. However, the basis of pre-conceptual testing comes from valid manifestation or converge at the test result of CFA (Confirmatory Factor Analysis). The eliminated manifestations are not used anymore as suggested by modification indeces. The test of convergent validity and composite reliability is applied to provide level of model unity. Convergent validity is found out by comparing factor loading value with unmeasured coeficient which is 1 - error. If factor loading value is higer than unmeasured coeficient. Therefore, the manifestation has validity; however, composite realibility in as formulated in $\frac{\left(\sum \lambda\right)^{2}}{(\Sigma \lambda)^{2}+(\Sigma e)}$ (Bagozzi in

Hasan, 1998; Ferdinand, 2002; Teo and Lim, 2001). The result and reability of the research of research model is presented in the following table:

Tabel 2.Convergent Validity and Composite Reliability

\begin{tabular}{|c|c|c|c|c|}
\hline No & Indicator & $\begin{array}{c}\text { Loading } \\
(\lambda)\end{array}$ & $(1-e)$ & Conclusion \\
\hline 1 & $\begin{array}{l}\text { Learning Organization } \\
\text { Training }\left(\mathrm{X}_{2 \cdot 1}\right) \\
\text { Mentoring }\left(\mathrm{X}_{2 \cdot 2}\right) \\
\text { Experience }\left(\mathrm{X}_{2 \cdot 3}\right) \\
\text { Composite Reliability }=0.975\end{array}$ & $\begin{array}{l}0.86 \\
0.66 \\
0.72\end{array}$ & $\begin{array}{l}0.05 \\
0.04 \\
0.04\end{array}$ & $\begin{array}{c}\text { Valid } \\
\text { Valid } \\
\text { Valid } \\
\text { Reliable }\end{array}$ \\
\hline 2 & $\begin{array}{l}\text { Community Empowerment } \\
\text { Business skill training }\left(\mathrm{X}_{3.1}\right) \\
\text { Business Counseling }\left(\mathrm{X}_{3.2}\right) \\
\text { Business Facility }\left(\mathrm{X}_{3.3}\right) \\
\text { Composite Reliability }=0.975\end{array}$ & $\begin{array}{l}0.86 \\
0.66 \\
0.72\end{array}$ & $\begin{array}{l}0.05 \\
0.04 \\
0.04\end{array}$ & $\begin{array}{c}\text { Valid } \\
\text { Valid } \\
\text { Valid } \\
\text { Reliable }\end{array}$ \\
\hline 3 & $\begin{array}{l}\text { Organizational Commitment } \\
\text { Affective }\left(\mathrm{Y}_{1.1}\right) \\
\text { Sustainable }\left(\mathrm{Y}_{1.2}\right) \\
\text { Normative }\left(\mathrm{Y}_{1.3}\right) \\
\text { Composite Reliability }=0.975 \\
\end{array}$ & $\begin{array}{l}0.86 \\
0.66 \\
0.72\end{array}$ & $\begin{array}{l}0.05 \\
0.04 \\
0.04\end{array}$ & $\begin{array}{c}\text { Valid } \\
\text { Valid } \\
\text { Valid } \\
\text { Reliable } \\
\end{array}$ \\
\hline 4 & $\begin{array}{l}\text { MSMEs Performance } \\
\text { Set aside profit }\left(\mathrm{Y}_{2.3}\right) \\
\text { The last three years growth of product quantity }\left(\mathrm{Y}_{2.4}\right) \\
\text { Market reach }\left(\mathrm{Y}_{2.5}\right) \\
\text { Conflict frequency of society due to the use of tools or machine }\left(\mathrm{Y}_{2.9}\right) \\
\text { Composite Reliability } 0.981\end{array}$ & $\begin{array}{l}0.62 \\
0.80 \\
0.69 \\
0.77\end{array}$ & $\begin{array}{l}0.04 \\
0.04 \\
0.03 \\
0.05\end{array}$ & $\begin{array}{l}\text { Valid } \\
\text { Valid } \\
\text { Valid } \\
\text { Valid } \\
\text { Reliable }\end{array}$ \\
\hline
\end{tabular}

Source: Data Processed (2018)

The model of research result has fulfilled the principle of validity and realibility. It is according to the view of Tull and Hawkins (1987), Malhotra (in Solimun, 2002), and Jogaratnam and Buchanan (2004) who stated that the acquisition of coefficient-reliability is more than 0.60 considered sufficient. Generally, this criterion is 
acceptable.

The calibration result of the direct and indirect influence from one variable to the other variables presented in the following table:

Table 3. Direct and Indirect Influence

\begin{tabular}{|c|c|c|c|c|c|}
\hline \multirow{2}{*}{ No } & \multirow{2}{*}{ Calibration } & \multicolumn{3}{|c|}{ Coefficient of Influence } & \multirow[t]{2}{*}{ Information } \\
\hline & & Direct & Indirect & Total & \\
\hline 1 & $\begin{array}{l}\text { Learning Organization --> } \\
\text { Organizational Commitment }\end{array}$ & $\begin{array}{c}0.34 \\
(6.62)\end{array}$ & - & 0.34 & Significant \\
\hline 2 & $\begin{array}{l}\text { Community Empowerment --> } \\
\text { Organizational Commitment }\end{array}$ & $\begin{array}{c}0.30 \\
(5.79)\end{array}$ & - & 0.30 & Significant \\
\hline 3 & $\begin{array}{l}\text { Learning Organization --> } \\
\text { MSMEs Performance }\end{array}$ & $\begin{array}{c}0.22 \\
(4.10) \\
\end{array}$ & - & 0.22 & Significant \\
\hline 4 & $\begin{array}{l}\text { Community Empowerment --> } \\
\text { MSMEs Performance }\end{array}$ & $\begin{array}{c}0.42 \\
(7.76)\end{array}$ & - & 0.42 & Significant \\
\hline
\end{tabular}

Source: Data Processed (2018)

Information : Number in parenthesis () presenting T-value; T-value $>$ T-table (1.96) is significant

Based on the calibration above, it is stated that the influence is significant between learning organization toward organizational commitment, community empowerment toward organizational commitment, learning organization toward MSMEs performance, community empowerment toward MSMEs performance. The result of hypothesis proof is presented in the following table:

Table 4. Respondent Perception toward Indicator of Research Variable

\begin{tabular}{|l|c|c|c|}
\hline Variable & Indicator & Loading Factor & Mean \\
\hline Learning Organization & $\mathrm{X}_{2.1}$ & 0.86 & 3.6 \\
\hline \multirow{3}{*}{ Community Empowerment } & $\mathrm{X}_{2.2}$ & 0.66 & 3.8 \\
\cline { 2 - 4 } & $\mathrm{X}_{2.3}$ & 0.72 & 3.7 \\
\hline Organizational Commitment & $\mathrm{X}_{3.1}$ & 0.86 & 3.8 \\
\hline \multirow{3}{*}{ MSMEs Performance } & $\mathrm{X}_{3.2}$ & 0.66 & 3.9 \\
\cline { 2 - 4 } & $\mathrm{X}_{3.3}$ & 0.72 & 3.5 \\
\hline \multirow{3}{*}{} & $\mathrm{Y}_{1.1}$ & 0.86 & 3.6 \\
\cline { 2 - 4 } & $\mathrm{Y}_{1.2}$ & 0.66 & 3.6 \\
\cline { 2 - 4 } & $\mathrm{Y}_{1.3}$ & 0.72 & 3.6 \\
\cline { 2 - 4 } & $\mathrm{Y}_{2.3}$ & 0.64 & 3.6 \\
\cline { 2 - 4 } & $\mathrm{Y}_{2.4}$ & 0.80 & 3.5 \\
\cline { 2 - 4 } & $\mathrm{Y}_{2.5}$ & 0.69 & 3.6 \\
\hline
\end{tabular}

Source: Processed Data (2018)

\subsection{Discussion \\ Learning organization influences to organizational commitment}

The hypothesis calibration 2, the estimated result on the research model presents the value of T-value is $6.62(>$ $t_{\text {tabel }}$ 1.96) has strong value and shows significant. It means that learning organization has direct influence to the organizational commitment or proven. The finding of research result discovers that direct influence of learning organization toward organizational commitment is valued as 0.34 . Learning organization contains training manifestation, mentoring, and experience. From the third manifestation has high loading value from one of learning organization manifestation which is mentoring. Strong employee training will affect to employee commitment and will influence to the improvement of MSMEs performance. It is in line with research result of Xianting Y. Fungfai, NG (2010) discovers that the culture of organization learning has positive relationship with practice guidance, practice guidance affects on organizational commitment, the culture of organization learning has positive relationship to the organizational commitment through practice guidance. The research resulit is in line with the previous research by Jun jo, S, Kyoo, B.J (2011), Chaoo, Lee (2007), Egan, Yang Barlett (2004) Kyoo, B.J. (2011), Xianting Y. Fungfai, NG (2010), Tseng, C. (2010).

\section{Community Empowerment affects directly to the Organizational Commitment}

From the third hypothesis calibration, estimated result on research model presents value T-value of 5.79 ( $>$ $\left.t_{\text {tabel }} 1.96\right)$. It indicates strong value and significant which means that community empowerment has direct influence to the organizational commitment, and it is proven. Research finding finds out that direct influence of community empowerment toward total influence of organizational commitment is 0.30 . The implication of empowerment 
especially in manifest (business facility) of company is adequate provided. The adequate facility affects on organizational commitment of employee. Facility defines as the process (accompaniment) which are condicted in social groups in village. It relates to the problem of MSMEs which will result business in MSMEs which affects on people commitment to be more independently productive for being entrepreneur. Community empowerment affects the organizational commitment in line with the previous research (Corsun and Enz (1999). Koberg et al., (1999).

\section{Learning organization gives direct influence to MSMEs performance}

From the sixth hypothesis calibration, estimated result on research model presents that the value of T-value is 4.10( $\left.>t_{\text {tabel }} 1.96\right)$. It indicates significant and strong value which means that learning organization has direct influence to the MSMEs, and it is proven. It finds out that the influence of learning organization toward MSMEs performance is 0.22 in total. It means that learning organization will affect to MSMEs performance if employees have strong learning organization through the training, mentoring, and experience process; therefore it affects to the improvement of the performance of MSMEs company. This research is in line with the previous research from Hurly and Hult (1998), Yani Antariksa (2000).

The community empowerment gives direct influence to the MSMEs performance

From the seventh hypothesis calibration, estimated result on research model presents that the value of T-value is 7.76( $\left.>\mathrm{t}_{\text {tabel }} 1.96\right)$ which indicates strong and significant value. It defines community empowerment that has direct influence to MSMEs performance, and it is proven. The research result has direct influence on community empowerment toward MSMEs performance which is 0.42 which presents through community empowerment in business facility manifestation. If facility of technology or machine equipment is fulfilled therefore it affects on MSMEs performance. In the process of facilitation which is conducted will result independent business in MSMEs affecting to the improvement of entrepreneur's quality of life. The impact of community empowerment will affect to the improvement of life quality of MSMEs's owners. It is in line with the previous research from M.J. Xavier, J. Raja and S. Usha Nanhini (2006), Guy Vincent (2005), Robert C. Rice (2000).

\section{Conclusion}

1. Learning Organization directly affects to the Organizational Commitment. Value of T-value as 6.62( $\left.>\mathrm{t}_{\text {tabel }} 1.96\right)$ has strong value and presents significant. The research results find out that learning organization directly affects to the organizational commitment or called proven. The total influence value is 0.34 which results mentoring manifestation (practice guidance) positively affects to the organizational commitment, cultural learning organization which has positive relationship with organizational commitment through practice guidance.

2. Community empowerment directly affects to the organizational commitment. Value of T-value as 5.79(> $t_{\text {tabel }}$ 1.96) presents strong value and it is significant. The research result proves that community empowerment directly affects to the organizational commitment or called proven. The total of influence scale is 0.30 which means that a company provides sufficient business equipment in technology; therefore, it can results the employee commitment. It can be seen from the implication of empowerment especially in facilities for the process of facilitation conducted by social groups in village which work on MSMEs. It results the independence to run business of MSMEs. It affects to the people's commitment to work extra for independent entrepreneurship. It concludes that community empowerment can affect to organizational commitment.

3. Learning Organization directly affects tothe MSMEs performance. It results that learning organization directly affects to the MSMEs performance, and it is proven. Learning organization gives impact to the MSMEs performance unless employee have learned about learning organization through training, mentoring, and experience. Therefore, it will affect to the improvement of MSMEs company's performance.

4. Community empowerment directly affects to the MSMEs performance. It results that community empowerment gives direct influences to the MSMEs performance, and it is proven. Facilitation which has been conducted can results independence of running the business of MSMEs. It affects to the improvement of entrepreneur's quality of life. Therefore, it concludes that community empowerment can affects to the improvement of MSMEs entrepreneur's life.

\section{References}

Ackfeldt, A.L., dan Coote, L.V., 2000. An investigation into the antecedents of organizational citizenship behaviours, ANZMAC,Visionary Marketing for the $21^{\text {st }}$ Century: Facing the Challenge.

Arbuckle, Jl., dan Wothke, W., 1999. Amos 4.0 User's Guide. Chicago: SmallWaters Corporation. Azwar, Saifuddin. 1995. Sikap Manusia Teori dan Pengukurannya.Yogyakarta: Pustaka Pelajar Brown TL, 1990., match up with a mentor industry weak, volume 239, October.

Byrave, W.D 1994. The Portable MBA in Entrepreneurship. Jhon Willey \& Sons, Inc.New York. 
Budiretnowati, 6 -12- 2008.Kajian tentang profil UMKM (online) hhtp://www. Smeeda.com/kajian/files/jurnal 3 2008/03 gunari.pdf.accessed on January 2014.

Cassel, C., Nadin, S., Gray M., and clegg C. 2002, management practices in small and medium sized Entreprises. Personel Review, 31:671- 695.

Coolican, H., 1994. Research Methods and Statistics in Psychology. London: Hodder\& Stoughton.

Chen, Z.X., 1998. The effects of loyalty in supervisor on job satisfaction and intention to stay: a Chinese case. Paper, Hongkong: School of Business, Hongkong Baptist University.

Chuang, Y., Church, R., dan Zikic, J., 2004.Organizational culture, group diversity and intra-group conflict.The Performance Management, 10 (1/2): 26-34.

Chao,C.S Lee., S.M. 2007, A Study on relationship among leadership, organization; Culture, the operation of learning Organization and Employees Job Satisfaction, The Learning Organization, Vol 14 No. 2, pp.155185.

Drucker P,F, 1994. Inovasi dan Kewirausahaan (Inovation and Entrepreneurship). Airlangga

Daniel, W.W., dan Terrel, J.C., 1989. Business Statistics for Management and Economics. Boston: Houghton Mifflin Company.

Egan, T.M Yang, B Barlett, K.R. 2004, the Effect or organizational Learning Culture and job Satisfaction on Motivation to transfer Learning and Turnover Intention, Human Resource Development Quarterly, Vol 15, No. 3, pp 279-301.

Elzbieta, (2005). "Predictors of Organizational Commitment Among Staff in Assisted Living." The Gerontological Societyof America Vol. 45, No. 2, 196-205.

Freund, A., dan Carmeli, A., 2003. An empirical assessment: reconstructed model for five universal forms of work commitment. Journal of Managerial Psychology, 18 (7): 708-725.

Greenberg, Jerald and Robert A. Baron. 1997. Behavior in Organizations. New Jersey: prentice-Hall International, Inc.,

Greenberg, J. and Baron, R. A. 2003.Behavior in Organizations: Understanding and Managing the Human Side of Work. New Jersey: Pearson Education International.

Gujarati, D.N., 1995. Basic Econometrics. New York: McGraw-Hill, Inc.

Gay,L.R.,dan Diehl, P.L.,1992. Research Methods for Business and Management. New York: Macmillan Publishing Company.

Guy,V(nd); Sustainable micro-entrepreneurship: the Roles of microfinance, Entrepreneurship and sustainability in reducing poverty in developing country.(journal of business and social science vol. 4).

Hardinyah, 2008. Lingkungan, Masyarakat danTanggung Jawab Sosial Perusahaan CSR (Online) http://fema.ipb.acid/index.php/lingkungan-masyarakatdan tanggung jawab sosial perusahaan-csr.

Haryanti, 2006. Analisis faktor-faktor yang menjadi Prediktor organisasi pembelajaran Untuk meningkatkan kinerja karyawan. Tesis UNDIP Semarang.

Hurley,Robert F.and G.Thomas,M.Hult,1998. Innovation,Market Orientation, and Organizational Learning an Integration and Empirical Examination. Journal of Marketing, Vol. 62, p. 42-54.

Hasan, M.Z., 1998. Analisis Faktor. Makalah disampaikan pada lokakarya statistik dan analisis data penelitian, Malang: Lembaga Penelitian Universitas Negeri Malang (IKIP Malang).

Jun Jo, S, Baek K.J ,2011, Knowladge Sharing : The influences of learning Organization Culture, Organizational Commiment and Organizational Citizienship Behaviors, Journal Commitment and Organizational Citizenship Behaviors, Journal of leadership \& Organizational Studies, Vol 25 No 4, pp 11 -14.

Jennifer M.G \& Jones G.R, 2007.Understanding and Managing Organizational Behaviour.Fifth Edition.Pearson Prentice Hall. New Jersey.

Jernigan III, I.E., Beggs, J.M., danKohut, G.F., 2002. Dimensions of work satisfaction as predictors of commitment type.Journal of Managerial Psychology, 17 (7): 564-579.

Jogaratnam, G., dan Buchanan, P., 2004.Balancing the demands of school and work: stress and employed hospitality students.International Journal of Contemporary Hospitality Management, 16 (4): 237-245.

Kyoo, B.J Park, S. 2010 Career satisfaction, organizational commitment and turnover intention. The effect of goal orientation, organization learning culture and development feedback, Leadership \& Organizational Studies, Vol 16, No 1 pp 48-60.

Kreitner, Robert And Angelo Kinicki. 2005. Perilaku Organisasi, Edisi 5. Alih bahasa Erly Suandy. Jakarta: Salemba Empat.

Kusnendi, 2006. Pengaruh kompetensi,komitmen dan Budaya organisasi terhadap Aktualisasi peran manejer serta Efektivitas organisasi (survei pada jasa BPR di wilayah kerja kantor bank indonesia bandung)." Bandung: Pascasarjana Universitas Padjadjaran.

Kreitner, R., and Kinicki, A., 2008. Organizational Behavior.8th Edition. New York: McGraw-Hill.

Keller, R. T. 1997. Job Involvement and Organizational Commitment as Longitudinal Predictors of Job Performance: A Study of Scientists and Engineers. Journal of Applied Psychology 82(4): 539- 545. 
Kewo, C. L., \& Afiah, N. N. (2017). Does Quality of Financial Statement Affected by Internal Control System and Internal Audit? International Journal of Economics and Financial Issues, 7(2), 568-573.

Kewo, C. L. Pengaruh Penganggaran Partisipatif, Komitmen Organisasi Dan Pengendalian Intern Terhadap Kinerja Manajerial Aparatur Pemerintah Kabupaten Minahasa. Jurnal Riset Akuntansi dan Keuangan, 7(1), $29-42$.

Kunene, Thandeka R., 2008, A Critical Analysis of Entrepreneurial and Business Skills in SMEs in the Textil and Clothing Industry in Johannesburgh, South Africa, University of Pretoria.

Lipshitz, R., Popper, M., \& Friedman, V. J. (2002).A multifaceted model of organizational learning.The Journal of Applied Behavioral Science, 38(1), 78-98.

Luthan, Fred 2008 Organization Behavior, $11^{\text {th }}$ Edition: McGraw-Hill, Inc. International Edition New York.

Levitt, T. 1987. Imajinasi Pemasaran. Edisi Revisi. Terjemahan Agus Maulana. Jakarta : Erlangga.

Lok, P., dan Crawford, J., 2001.Antecedents of organizational commitment and the mediating role of job satisfaction.Journal of Managerial Psychology, 16 (8): 594-613.

Tambunan, Tulus, 2008. Masalah pengembangan UMKM di Indonesia: sebuah upaya mencari alternatif, bahan diskusi Forum kendala Economi Institut for Global Justice, jakarta, 28 september 2008.

Tseng, C. 2010, The Effects of learning organization Practices on Organizational Commitment and Efectiveness for small and medium- Size Enterprises in Taiwan, Dissertation Submitted to the Faculty of the Graduate School of the University of minnesota.

Meyer, J.P., Allen N. j \& Smith, Catheride A. 2003 HRM Practices and Organizational Commitment : Test of a Mediation Model. Canadian Journal of Administrative Science.Vol.7.No 4, pg.319-331.

McShane, Stephen L and Von Glinow, Mary Ann. 2005. Organizational Behavior: Emerging Realities for the Workplace Revolution, second Ed, McGrawHill, Irwin.

McCall, R.B., 1986. Fundamental Statistics for Behavioral Sciences. Sandiego: Harcourt Brace Jovanovich, Publishers.

M.J. Xavier, J Raja, S Usha Nandini (2007), impact of Entrepreneurship Development through corporate interventions; An Assessment of the case of $\mathrm{H}^{\prime \prime} \mathrm{LL}_{\mathrm{s}}$ Project shakti, (Advances in international management volume 20).

Moehariono, 2010.Pengukuran Kinerja Berbasis Kompetensi,Jakarta : Ghalia Indonesia.

Makinen, H. 2000. Product Design as Core Competence in a Design Oriented Industry. Turku School of Economics and Business Administration.

Meng, L.A, dan Liang, T.W. 1996. Entrepreneurs, Entrepreneurship and Entreprising Culture.Paris : AddisonWisley Publishing Company.

Moeljono, Djokosantoso. 2003. Budaya Korporat dan Keunggulan Korporasi. Jakarta: PT.Elex Media Komputindo.

Mondy, dan Noe.2005. Human Resource Management. Jakarta: PT Bumi Aksara.

Nasution, M.N. 2001 Manajemen Mutu Terpadu, Jakarta :Ghalia Indonesia.

Niehoff, B.P., dan Moorman, R.H., 1993. Justice as a mediator of relationship between methods of monitoring and organizational citizenship behavior.Academy of Management Journal, 36 (3): 527-556.

Odom, Rendal, Y., Boxx, W.R.,\& Dunn, M.G.1990. Organizational Culture, Commitment, Satisfaction, and Cohesion. Public Productivity \&Management Review, 14 (2), 157-169.

Oxaal, Z. dan Bade., S. 1997 Gender and Empowerment : Definitions, Approaches \& Implications for policy. Report 40 for the Swedish International Development Studies. University of Sussex, Brigton UK.

Prawirosentono, S., 1999, Manajemen Sumber Daya Manusia Kebijakan Kinerja Karyawan, Yogyakarta: BPFE. Pastin, 1986.The Hard Problem Of Management. Jossey Bass Inc., California, USA.

Peter, M., senge 1999, The Fifth Discipline Fieldbook. London: Nicholas Brealey publishing limited.

Robbin Stephen, and Judge, Timothy.2009. Organizational Behavior $13^{\text {th }}$ edition.Pearson International Edition.

Robert L. Mathis and John H.Jackson. 2006. Human Reources Mnagement. Salembah empat Jakarta.

Rusidi,1990, Dasar-dasar Penelitian. Bandung : Program Pascasarjan Universitas Padjajaran.

Riyanti, 2003. Kewirausahaan dari sudut pandang Psikologi Kepribadian.Jakarta : PT Grasindo.

Riyanti, B. Prihatin Dwi, 2004 Factors influencing the success of Small-Scale Entrepreneurs in Indonesia.

Rue, L.W. \& Byars, L. 1997. Management: Theory and Application, Homewood Illinois : Richard D. Irwin, Inc.

Roscoe, J.T., 1969. Fundamental Research Statistics for the Behavioral Science. New York: Holt, Rinehart and Winston, Inc.

Rice, C.R. 2000. Factors Affecting theCompetitiveness of small and Medium Enterprise in Indonesia. Workpaper PEG, Usaid (2000).

Siagian, S. P. 2002. Kiat meningkatkan produktivitas kerja. Jakarta :PT. BumiAksara.

Solimun, 2002.Multivariate Analysis, Structural Equation Modelling (SEM), Lisrel dan Amos, aplikasi di manajemen, ekonomi pembangunan, psikologi, sosial, kedokteran dan agro kompleks. Malang: Fakultas MIPA, Universitas Brawijaya. 
Spreitzer, G.M., 1995. Psychological empowerment in workplace: dimensions, measurement, and validation. Academy of Management Journal, 38(5), pp.1442-1465.

Sumodiningrat, G., 1999. Ekonometrika Pengantar. Yogyakarta: BPFE.

Suharto, E. 2005. Membangun Masyarakat Memberdayakan Rakyat, Kajian Strategies Pembangunan Kesejahteraan Sosial \& Pekerjaan Sosial, Refika

Suharyadi, Ariisetyanto N., Prwanto, S.K., dan Maman, F. 2007. Kewirausahaan; Membangun Usaha Sukses Sejak Usia Muda. Jakarta: Salemba Empat.

Sunaryanto, 2003. Analisis Sumber Daya Strategies sebagai Landasan Penetapan Strategi dan Pengaruhnya terhadap Kinerja Usaha Kecil dan Menengah (Bidang Usaha Konveksi di Jawa Timur). Disertasi. Program pasca sarjana Universitas Negeri Malang.

Sekaran, U., 2003. Research Methods for Business, a skill building approach. New York: John Wiley \& Sons, Inc.

Slater, S.F, and Narver, J.C. 1995. Market Orientation and the Learning Organization.Journal of Marketing, 59 : 63-74

Spreitzer, G.M., 1995. Psychological empowerment in workplace: dimensions, measurement, and validation. Academy of Management Journal, 38(5), pp.1442-1465

Tuckman, B.W., 1978. Conducting Educational Research. San Diego: Harcourt Brace Jovanovich, Publishers.

Tanjung, dan Hafidhudin, 2003 Manajamen Syariah Dalam Praktik, Jakarta: penerbit gema insani.

Tjakraatmadja, Jann Hidajat. 2006. Membangun Learning Organization: Mau berbagi, dalam seminar Sekolah Manajemen dan Bisnis ITB.www.itb.ac.id

Thomas, K. W., and Velthouse, B.A . (1990). "Cognitive Elements of Empow erment: A Interpretive ${ }^{e e}$ Model of Intrinsic Task Motivation. Academy of Management Review.Vol. 15, pp. 666-681.

Udan Biantoro, 2002. Pengaruh Praktek Manajemen Sumber Daya Manusia Terhadap Budaya Organisasi dan Kinerja Perusahaan.Disertasi Universitas Airlangga, Surabaya.

Undang - Undang No 28 Tahun 2008 tentang UMKM.

Wahjoedi, 2004.Tanggung Jawab Sosial Perusahaan Implementasi dan Makna Ekonomisnya bagi perusahaan dan Masyarakat Sekitar (Studi Kasus pada PT Pabrik kertas jawa timur) Tesis. Magister Perencanaan dan Kebijakan Publik Fakultas EkonomiUniversitas Indonesia.

Wong, Y.T., Ngo, H.Y., dan Wong, C.S., 2002. Affective organizational commitment of workers in Chinese joint ventures.Journal of Managerial Psychology, 17 (7): 580-598.

Wood, Jack. Chapman, Judith. Wallace, Joseph. Zeffane, Rachid, MZeffane 2004 Organisational Behaviour: A Global Perspective. 3rd.

W. Utomo, Tri., Widodo.2004. Beberapa Permasalahan Dan Upaya Akselerasi Program Pemberdayaan Masyarakat. Nagoya University.

Yanghoubi, M., Raesi, A, Afshar M, Yarmohammadian, M.H. Hasanzadeh, A Javadi, M, Ansary M (2010), the relationship between the learning organization and organizational commitment among managers in educational hospitals of Isfahan University of medical Sciences in 2008 -9, IJNMR, Vol 15, No2, pp 7884Edition, John Wiley \& Sons Australia, Ltd.

Xianting, Y., Fungfai, NG ,Learning Organization and Mentoring Practice : An Empirical Investigation, http/www. Eres 2010.Org/contents/paper/1d214.pdf accessed on 10 February 2014. 